ISSN Print : 1411 - 951 X, ISSN Online : 20503-1716

Jurnal Ergonomi Indonesia

(The Indonesian Journal of Ergonomic)

Vol.3, No.1 : 1 Januari-Juni 2017

\title{
MODIFIKASI KAMPIL PAKAN TERNAK BERBASIS ERGONOMI MEMPERBAIKI BEBAN KERJA DAN MENINGKATKAN RODUKTIVITAS KERJA PEKERJA PETERNAKAN AYAM BROILER
}

\author{
${ }^{1}$ I Kadek Saputra, 2Ketut Tirtayasa, 3I Nyoman Sucipta. \\ 1. Mahasiswa Program Studi Magister Ergonomi Fisiologi Kerja Universitas Udayana \\ 2. Staff Dosen Program Studi Magister Ergonomi Fisiologi Universitas Udayana \\ 3. Staff Dosen Program Studi Magister Ergonomi Fisiologi Universitas Udayana \\ ${ }^{1}$ kadek.saputra@yahoo.com, ${ }^{2}$ ketut.tirtayasa@gmail.com, ${ }^{3}$ sucipta@unud.ac.id
}

\begin{abstract}
ABSTRAK
Salah satu kegiatan penting dalam proses pemeliharaan ayam broiler adalah pemberian pakan yang biasa dilakukan dengan menggunakan gayung. Dilihat dari sikap, lama kerja, frekwensi pengulangan dan beban angkut, alat dan cara tersebut kurang ergonomis sehingga dapat memperberat beban kerja dan mempengaruhi produktivitas pekerja. Penelitian ini bertujuan untuk membuktikan intervensi berupa modifikasi kampil pakan ternak berbasis ergonomi bermanfaat bagi pekerja melalui perbaikan beban kerja dan peningkatan produktivitas kerja pekerja peternakan ayam broiler.

Penelitian eksperimental dirancang menggunakan disain pretest-posttest control group design. Sampel sebanyak 20 orang diambil dengan metode acak sederhana yang kemudian dibagi menjadi kelompok kontrol dengan intervensi menggunakan gayung dan kelompok eksperimen dengan menggunakan modifikasi kampil pakan berbasis ergonomi. Penelitian dilakukan pada bulan Juni-Juli 2016. Variabel yang dievaluasi adalah beban kerja dan produktivitas kerja.

Hasil penelitian didapatkan, modifikasi kampil pakan berbasis ergonomi berpengaruh secara signifikan $(\mathrm{p}<0,05)$ dalam memperbaiki beban kerja dan meningkatkan produktivitas kerja. Terjadi penurunan denyut nadi sebesar 13,7\%, penurunan cardiovascular load sebesar $51 \%$, peningkatkan produktivitas sebesar $58,6 \%$ dan penghematan waktu kerja sebesar $51,9 \%$.

Dapat disimpulkan bawa penggunaan modifikasi kampil pakan berbasis ergonomi dapat memperbaiki beban kerja dan meningkatkan produktivitas kerja melalui perbaikan sikap kerja, lama waktu kerja dan berat beban angkut. Diharapkan hasil penelitian ini dapat digunakan oleh para pekerja peternakan ayam broiler sehingga status kesehatan dapat meningkat.
\end{abstract}

Kata kunci: modifikasi kampil pakan, ergonomi, beban kerja, produktivitas 


\section{ABSTRACT \\ FEEDING BAG MODIFICATION ERGONOMICLY BASIS IMPROVING PHYSIOLOGYCAL PARAMETERS AND INCREASING PRODUCTIVITY AMONG BROILER FARM WORKERS}

One of important activity on broiler management is providing feed. Plastic bailer use to be use as supporting equipment. Base on working posture, working duration, repeating frequency and load haul it does not follow the ergonomic principles. Therefore, it can influence working load and productivity of farm worker. This research aim to prove that ergonomic intervention such feeding bag modification base on ergonomic can improve work load and increase work productivity of broiler farm worker.

This research is designed using pretest-posttest control group design. Twenty samples were selected with simple random sampling method and then allocated in to control group that use plastic bailer and intervention group that use feeding bag modification base on ergonomics to administer feed. The research was done in Suwegita Putra Chick Farm house located in desa Pajahan, Kec Pupuan, Kab Tabanan on Juni until Juli 2016. Evaluated variables were work load and work productivity of samples of broiler farm workers

Research findings found that were decreasing heart rate about $13.7 \%$, decreas cardiovascular load about $51 \%$, increasing work productivity about $58.6 \%$, and save the administration time about $51.9 \%$. Therefore feeding bag modification base on ergonomic was significant $(\mathrm{p}<0.005)$ improving work load and work productivity.

It could be concluded that feeding bag modification base on ergonomic improve work load and increase work productivity of broiler farm worker through work posture and work duration improvement, load haul adjustment. Finally, it can be expected that the research benefits can be implemented daily by broiler farm worker to achieve better general status.

Key words: feeding bag modification, ergonomic, work load, productivity

\section{PENDAHULUAN}

Usaha peternakan ayam broiler terus berkembang seiring dengan peningkatan kebutuhan daging ayam akibat penambahan jumlah penduduk dan peningkatan status sosial ekonomi masyarakat. Ayam broiler merupakan salah satu ternak unggas hasil budidaya yang bersifat ekonomis dengan pertumbuhan yang cukup cepat dalam menghasilkan daging yang siap potong dengan lama budidaya yang relatif singkat baik jenis jantan maupun betina (Rasyaf, 2006). Untuk mencapai hasil yang optimal, peternak harus cermat melakukan pemeliharaan dengan melakukan manajemen nutrisi dan manajemen lingkungan yang baik.
Salah satu kegiatan penting dalam manajemen nutrisi ayam broiler adalah pemberian pakan. Pakan diberikan untuk memenuhi kebutuhan ayam akan protein, karbohidrat, lemak dan serat untuk mendukung pertumbuhan yang cepat (Mideon, 2014a). Menurut Fadilah (2004) kebutuhan pakan meningkat setiap hari. Studi pendahuluan yang dilakukan di Desa Pajahan Kec Pupuan Tabanan, didapatkan jumlah kandang yang ada sebanyak 23 kandang dengan populasi antara $3000-12000$ ekor. Salah satu pekerjaan utama setiap hari adalah pemberian pakan. Dari tiga kandang yang diobservasi, semua pekerja memberikan pakan secara manual dengan menggunakan "gayung". Gayung merupakan alat yang terbuat tempurung, plastik dan 


\section{Jurnal Ergonomi Indonesia}

\section{(The Indonesian Journal of Ergonomic)}

sebagainya yang diberi tangkai untuk mengambil air, sibur, dan bahan lainnya (KBBI, 2016). Dengan menggunakan gayung, mengambil dan menuangkan pakan dilakukan dengan posisi membungkuk dan frekwensi yang sangat tinggi. Untuk mengisi $3 \mathrm{~kg}$ pakan pada satu tempat pakan, pekerja perlu menuangkan gayung sebanyak 4 kali. Sehingga frekwensi total membungkuk untuk 200 tempat pakan sebanyak 800 kali setiap hari.

Jika posisi ini dianalisis dengan metode OWAS (Ovako Working Analysis System), didapatkan skor akhir OWAS adalah 3 yang termasuk dalam kategori risiko tinggi dan mempunyai efek berbahaya pada sistem muskuloskeletal. Sehingga rekomendasi untuk pekerjaan dengan tingkat risiko tinggi adalah tindakan korektif diperlukan segera. Kondisi kerja yang tidak fisiologis akan dapat menyebabkan pekerja mengalami kelelahan dan keluhan muskuloskeletal (Richardson., dkk, 2006; Manuaba, 1992). Menurut Kroemer dan Grandjean (2009) dan Manuaba (2005a) untuk mencapai hasil kerja yang optimal, seorang pekerja harus bekerja dalam kondisi aman, nyaman dan terhidar dari gangguan kesehatan termasuk gangguan muskuloskeletal.

Untuk mengatasi permasalahan tersebut, perlu dilakukan intervensi ergonomi secara komprehensif. Mengingat kemampuan peternak yang terbatas, maka setiap intervensi ergonomi sebaiknya dirancang dalam sebuah konsep yang sederhana dan hendaknya disesuaikan dengan kemampuan finansial serta kemampuan sumber daya yang dimiliki peternak. Konsep yang dapat diterapkan adalah model pendekatan ergonomi total (SHIP approach dan implementasi teknologi tepat guna) yang diterapkan secara "built-in" dengan harapan setiap intervensi ergonomi dapat diterima dan
Vol.3, No.1 : 1 Januari-Juni 2017

diterapkan secara berkelanjutan tanpa menimbulkan masalah baru yang berarti (Manuaba, 2003; Manuaba, 2005a).

Alternatif pemecahan masalah yang digunakan adalah dimodifikasi kampil pakan yang dirancang menggunakan prinsip ergonomi. Kampil pakan merupakan sebuah istilah yang digunakan dalam dunia peternakan untuk kantong pakan yang mempunyai volume tertentu (KBBI, 2016). Kampil pakan konturnya lentur sehingga mudah dipegang dan mudah diarahkan ke mulut tempat pakan. Dengan tersebut, pemberian pakan dilakukan dalam posisi berdiri tegak dan frekwensi penuangan hanya sekali untuk setiap tempat pakan. Dengan perubahan posisi dan cara kerja ini maka kontraksi otot skeletal dapat dikurangi sehingga parameter fisiologis beban kerja dapat diturunkan dan produktivitas pekerja di peternakan ayam broiler dapat ditingkatkan.

\section{METODE PENELITIAN}

\section{Rancangan Penelitian \\ Jenis penelitian ini adalah penelitian eksperimen dengan menggunakan rancangan pretest-posttest dengan kelompok kontrol (pretest- posttest control group design).}

\section{Populasi dan Sampel}

Populasi dalam penelitian ini adalah para pekerja peternakan ayam broiler yang berlokasi di desa Pajahan Kecamatan Pupuan Kabupaten Tabanan yang berjenis kelamin laki-laki sebanyak 34 orang. Sampel diambil sebanyak 20 orang dengan menggunakan rumus Pocock, (2008) dengan metode sampling acak sederhana (simple random sampling).

\section{Variabel dan Instrumen Penelitian}

1. Alat pemberian pakan merupakan alat yang digunakan untuk memberikan pakan dengan 


\section{Jurnal Ergonomi Indonesia}

\section{(The Indonesian Journal of Ergonomic)}

memindahkan pakan dari kampil pakan ke tempat pakan berupa (a) gayung (Gambar 1) dan (b) berupa dimodifikasi kampil pakan berbasis ergonomi (Gambar 2).

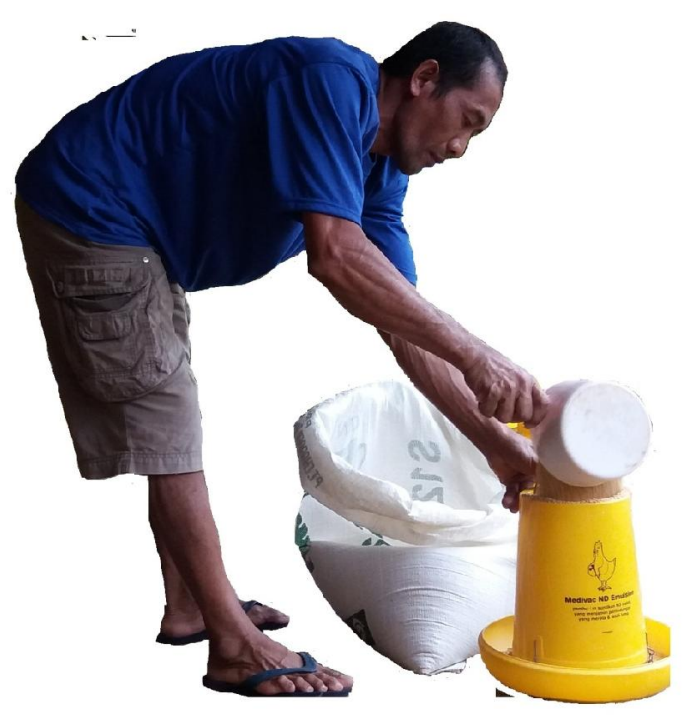

Gambar 1

Pemberian Pakan Dengan Gayung

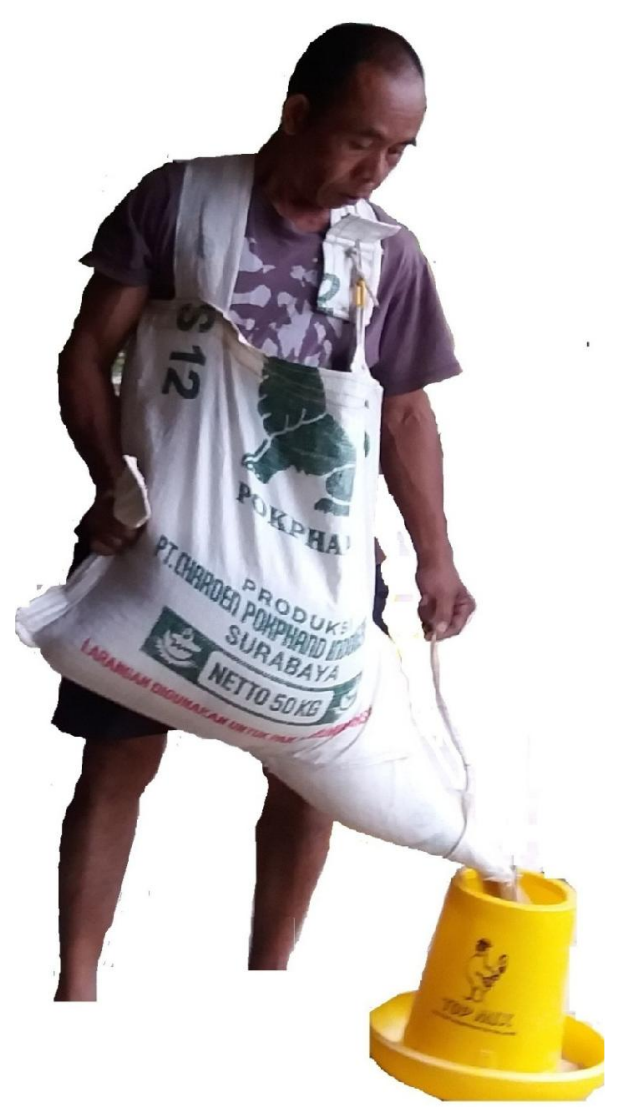

Gambar 2

Pemberian Pakan Dengan Modifikasi Kampil Pakan

2. Parameter fisiologis beban kerja diukur dengan menghitung denyut nadi (Kroemer dan Grandjean, 2009) dan persentase CVL (Intaranont \& Vanwonterghem, 1993)

3. Produktivitas dihitung dengna membandingkan antara jumlah keluaran (output) dengan masukan (input) dan waktu. Output

\section{Tempat dan Waktu Penelitian}

Penelitian dilakukan pada bulan Juni sampai Juli 2016 di kandang ayam broiler Suwegita Putra Farm di Desa Pajahan Kecamatan Pupuan Kabupaten Tabanan, Bali.

\section{HASIL PENELITIAN}

\section{Karakteristik Subjek Penelitian}

Tabel 1

Karakteristik Subjek Penelitian

\begin{tabular}{lrl}
\hline \multicolumn{1}{c}{ Uraian } & Rerata \pm SB & Rentang \\
\hline Umur (th) & $38,15 \pm 7,18$ & $28-50$ \\
IMT (kg/m2) & $22,76 \pm 1,95$ & $20-27$ \\
Pengalaman Kerja (bln) & $33,00 \pm 16,1$ & $6-60$ \\
$\begin{array}{l}\text { Denyut Nadi Istirahat } \\
\text { (dpm) }\end{array}$ & $68,70 \pm 7,12$ & $55-81$ \\
\hline
\end{tabular}

Dari tabel 1 dapat disimpulkan, responden termasuk dalam rentang usia kerja produktif (15-64 tahun) (DPRRI. 2003), IMT (index masa tubuh) dalam kisaran normal antara $18,5-22,9 \mathrm{~kg} / \mathrm{m}^{2}$ (Sugondo, 2006), mempunyai pengalaman pemberian pakan yang cukup (lebih dari 3 periode panen) dan mempunyai rentang denyut nadi dalam batas normal antara $60-80 \mathrm{dpm}$ sehingga menunjukkan fungsi jantung 


\section{Jurnal Ergonomi Indonesia}

(The Indonesian Journal of Ergonomic)

pembebanan otot rangka berkurang, maka kebutuhan oksigen, energi dan panas yang dihasilkan berkurang sehingga menyebabkan penurunan beban kardiovaskuler yang dapat dilihat dari penurunan denyut nadi (Guyton dan Hall, 2007). Hal ini ditunjang oleh beberapa penelitian ergonomi juga menunjukkan penurunan respon fisiologis beban kerja setelah dilakukan perbaikan posisi kerja (Dinata $\mathrm{dkk}$, 2015; Lestari, 2012).

\section{Produktivitas Kerja}

Tabel 7

Hasil Analisis Variabel Produktivitas Kerja

\begin{tabular}{|c|c|c|c|c|}
\hline \multirow{3}{*}{ Uraian } & \multicolumn{2}{|c|}{ Kelompok } & \multicolumn{2}{|c|}{$\begin{array}{c}\text { Uji } \\
\text { Komparabilitas }\end{array}$} \\
\hline & $\mathrm{P} 0$ & $\mathrm{P} 1$ & & \\
\hline & $\begin{array}{c}\text { Rerata } \pm \\
\text { SB }\end{array}$ & $\begin{array}{c}\text { Rerata }+ \\
\text { SB }\end{array}$ & $\mathrm{t}$ & $\mathrm{p}$ \\
\hline $\begin{array}{l}\text { Waktu } \\
\text { penyelesaian } \\
\text { (mnt) }\end{array}$ & $\begin{array}{l}44,5 \pm \\
5,3\end{array}$ & $\begin{array}{l}21,4 \pm \\
4,10\end{array}$ & 10,83 & 0,000 \\
\hline $\begin{array}{l}\text { Produktivitas } \\
\text { kerja }\end{array}$ & $\begin{array}{l}0,063 \pm \\
0,008\end{array}$ & $\begin{array}{l}0,15 \pm \\
0,01\end{array}$ & $\begin{array}{l}- \\
15.59\end{array}$ & 0,000 \\
\hline
\end{tabular}

Pada Tabel 6 dapat dilihat bahwa total waktu pelaksanaan pemberian pakan dengan menggunakan kampil pakan modifikasi (P1) selama 21,4 menit, lebih cepat dari penggunaan gayung (P0) yang membutuhkan waktu selama 44,5 menit. Terjadi penghematan waktu sebayak 23.1 menit atau sebesar $51,9 \%$ pada P1 terhadap P0. Dengan uji $t$ independent, lama waktu pemberian pakan kedua kelompok tersebut terbukti berbeda secara signifikan $(p<0,05)$. Dilihat dari data variabel produktivitas pada Tabel 6, terjadi perbedaan secara signifikan $(p<0.05)$ pada kedua kelompok dimana P1 lebih produktif (dengan rerata 0,152 ) daripada $\mathrm{P} 0$ (dengan rerata 0,063) dan besar peningkatan produktivitas P1 terhadap P0 sebesar 58,6\%. Dari uraian di atas, dapat disimpulkan bahwa modifikasi
Vol.3, No.1 : 1 Januari-Juni 2017

kampil pakan terbukti lebih cepat dan meningkatkan produktivitas pekerja secara signifikan dalam pemberian pakan ayam broiler

Pada penelitian ini, peningkatan produktivitas disebabkan oleh berkurangnya waktu penyelesaian pekerjaan dan menurunnya denyut nadi pekerja dimana penggunaan kampil pakan modifikasi membutuhkan waktu lebih singkat dan denyut nadi lebih rendah. Berkurangnya kelelahan dan keluhan muskuloskeletal berpengaruh secara tidak langsung terhadap peningkatan produktivitas. Produktivitas merupakan perbandingan secara ilmu hitung antara jumlah yang dihasilkan dengan jumlah setiap sumber yang dipergunakan selama produksi berlangsung (Hasibuan, 2007).

Beberapa penelitian pendukung dan banyak bukti menunjukkan peningkatan produktivitas setelah diberikan intervensi ergonomi melalui redesain alat yang lama maupun penciptaan alat baru. Agung dan Riki (2010), Yusuf (2004), Lestari (2012), Loo dan Paul (2015), Yusuf (2016) mendapatkan hasil berupa peningkatan produktivitas kerja. Bahkan Sutjana (2015) menyatakan bahwa dalam membuat desain produksi harus memperhatikan kemampuan, kebolehan, serta batasan manusia guna memperkecil dampak negatif dan meningkatkan produktivitas atau kesejahteraan pengguna.

\section{DAFTAR PUSTAKA}

1. Agung, K., Riki, M. 2010. Perancangan Ulang Fasilitas Kerja pada Stasiun Cutting yang Ergonomis Guna Memperbaiki Posisi Kerja Operator Sebagai Upaya Peningkatan Produktivita Kerja, Studi Kasus di Perusahaan Anode Crome Yogyakarta. Jurnal Informatika. Vol.4, No. 2, Juli 2010. 


\section{Jurnal Ergonomi Indonesia}

(The Indonesian Journal of Ergonomic)

2. Dinata, K., Adiputra N., Adiatmika, P.G. 2015. Sikap kerja duduk-berdiri bergantian Menurunkan Kelelahan, Keluhan Muskuloskeletal serta Meningkatkan Produktivitas Kerja Penyetrika Wanita di Rumah Tangga. Journal Ergonomi Indonesia VOl: 1 no 1.

3. DPRRI. 2003. Undang-Undang no. 13 tahun 2003 tentang Ketenagakerjaaan

4. Fadilah, R. 2004. Ayam Broiler Komersial. Jakarta: Agromedia Pustaka Utama.

5. Guyton, A.C., dan Hall, J.E. 2007. Fisiologi Kedokteran. Jakarta: Penerbit Buku Kedokteran EGC.

6. Hasibuan, H., Malayu, S.P. 2007. Manajemen Sumber Daya Manusia. Jakarta: Bumi Aksara

7. Intaranont, $\mathrm{K}$ and Vanwonterghem, K. 1993. Study of exposure Limit in Contraining Climatic Conditions for Strenous Task: An Ergonomic Approach. Final Report. Bangkok : Chulangkom University Departement of Industrial Engeneering.

8. KBBI. 2016. Kamus Besar Bahasa Indonesia. Online http://kbbi.web.id/gayung. diakses tanggal 1 April 2016.

9. Kepmenkes. 2002. Keputusan Menteri Kesehatan Republik Indonesia nomor 1405/MENKES/SK/XI/2002 tentang Persyaratan Kesehatan Lingkungan Kerja Perkantoran dan Industri

10. Kroemer, K.H.E., and Grandjean, E. 2009. Fitting the Tasks to the Human, $4^{\text {th }} \mathrm{ed}$. London: Taylor \& Francis Inc

11. Lestari, A.S. 2012. Kondisi Kerja Memandikan Bayi yang Ergonomis Menurunkan Beban Kerja dan Mengurangi Keluhan Muskuloskeletal di Ruang Nifas. Prosiding seminar Nasional Ergonomi. Bandung: Program Studi
Vol.3, No.1 : 1 Januari-Juni 2017

Teknik Industri-Universitas Widyatama p.A7-10

12. Loo, H.S., Paul, H.P.Y. 2015. Effects of Two Ergonomic Inprovement in BrazingCoils ofAirHandler Units. Journal of Applied Ergonomics. Vol. 51 (3), p383-391. Published by Elsevier Ltd.

13. Manuaba, A. 1992. Pengaruh Ergonomi terhadap Produktifitas. Bunga Rampai Ergonomi. Vol 11. 1998.126-133. Denpasar: Program Studi Ergonomi Fisiologi Kerja Universitas Udayana.

14. Manuaba, A. 2003, Holistic Design is a Must to Attain Sustainable Product, The national seminar on Product Design and Development Industrial Engineering UK Maranatha, Bandung, 4-5 Juli

15. Manuaba, A. 2005a. Total Ergonomic Enhancing Productivity, Product Quality and Custumer Satisfaction. Prosiding Seminar Nasional II Peningkatan Kualitas Sistem Manufaktur dan Jasa. Yogyakarta: Forum Komunikasi Teknik Industri.

16. Mideon. 2014a. Kapan Sebaiknya Ayam Broiler Dipanen?. Online https://info.medion.co.id/index.php/c omponent/content/article/1-tatalaksana/1337-kapan-sebaiknyaayam-broiler-dipanen. diakses tanggal 31 Maret 2016

17. Pocock, S.J. 2008. Clinical Trial a practical Approach. John Willey \& Sons Chichester-New YorkBrisbane-Toronto-Singapore

18. Rasyaf, M. 2006. Beternak Ayam Pedaging. Jakarta: Penebar Swadaya.

19. Richardson, G.E., Jenkins, P.L., Strogatz, D., Bell, E.M., May, J.J. 2006. Development and Initial Assesment of Obejectif Fatigue Measures for Aple Harvest Work. Journal Aplied ergonomics. November, 37 (6): 719-727. 
ISSN Print : 1411 - 951 X, ISSN Online : 20503-1716

\section{Jurnal Ergonomi Indonesia}

\section{(The Indonesian Journal of Ergonomic)}

20. Sanders, M.S. \& Mc Cormic, E.J. 1997 Human Factor in Engineering and Design. New York; Mc. GrawHill Book Company.

21. Sugondo. 2006. Obesitas Dalam Buku Ajar Ilmu Penyakit Dalam Jilid III Edisi IV. Jakarta: FK UI

22. Sutjana, I.D.P. 2015. Aspek Ergonomi dan Risiko Psikososial di Tempat Kerja. The Indonesian Journal of Ergonomic. Vol.1,No.1. p1-9.

23. Yusuf, M. 2016. "Desain Alat Pelubang Plasik Mulsa dan Sistem Kerja dengan Intervensi Ergonomi Meningkatkan Produktivitas Kerja Petani di Bedugul Bali” (disertasi). Denpasar: Program Pasca Sarjana Universitas Udayana.

24. Yusuf, M. 2004. Penggunaan Gerinda Pengasah Modifikasi dan Perbaikakn Sikap Kerja dapat Menurunkan Beban Kerja dan Keluhan Subjektif serta Meningkatkan Produktivitas Kerja Perajin Permata Bagian Proses Penghalusan di Kelurahan Subagan Karangasem (Laporan Tesis). Denpasar: Universitas Udayana. 